\title{
Improving the Tools for Strategic Economic Planning at the Regional Level: Main Directions of the Search for New Solutions
}

\author{
Petr Iosifovich Burak ${ }^{1 *}$, Viktor Grigorievich Rostanets ${ }^{1}$, Aleksey Igorevich Kabalinsky ${ }^{2}$, Irina \\ Sergeevna Androshina ${ }^{3}$, Elena Viktorovna Shurinova ${ }^{3}$ \\ ${ }^{1}$ Institute of Regional Economic Research, Moscow, Russia \\ ${ }^{2}$ Finance University under the Government of the Russian Federation, Moscow, Russia \\ ${ }^{3}$ National Research University "Moscow Power Engineering Institute", Moscow, Russia
}

Received: 14/07/2020 Accepted: 29/09/2020 Published: 20/12/2020

\begin{abstract}
The article deals with the issues of improving the system of strategic planning of the economy in the regions (Russian Federation entities) in the context of contemporary national problems and world challenges. The authors summarize regional practice of socio-economic planning and assess the hierarchy and composition of existing strategic planning documents in the regions of the Russian Federation, as well as propose new types of prearranged documents as the most important planning institutions. The authors consider also the feasibility of forming regional and interregional coordination structures that perform the strategic planning functions, as well as note the importance and prospects of using information technologies in regional strategic goal setting, forecasting, and programming.
\end{abstract}

Keywords: Region, Strategic planning, Institutions, Methods

\section{Introduction}

Contemporary Russia increasingly manifests the desire of the authorities of regional entities, who are responsible for socioeconomic development of regions, to have scientifically grounded elaborations of the long-range projections of the economic development of the managed areas, as well as implementation mechanisms of long-term goals, which, first of all, are aimed at improving the living conditions of the population. Regional systems of long-range projection documents are being formed in the Russian Federation entities to ensure scientifically grounded goal-setting and management activities.

With the adoption in 2014 of federal law "On strategic planning in the Russian Federation", a unified system of strategic planning documents of socio-economic development was formed at the regional level as part of concepts, strategies, projections, state programs, and plans. Implementing the statutory requirements, the regions, as entities of the Russian Federation, have created in 2014-2020 a huge array of standard and often quite formal documents for regional long-range projection, which lack fresh breakthrough ideas and new approaches that are so necessary for Russia in the current context.

It is important to note that with the adoption of the federal law, as well as the Strategy of Spatial Development of the Russian Federation until 2025 [1], the discussion about the development trends of Russian regions, the long-range projection mechanisms of regional development, and a set of documents for long-term goal setting not only did not stop but rather intensified noticeably. The regional strategies developing process involves public representatives - experts, businessmen, and scholars from higher education institutions. They offer their alternative drafts of longrange projection documents. For example, members of the NorthWest Cooperation Association have elaborated a draft development strategy for the North-West region of the country. An important document named "Development concept of the Baikal Region: Basic hypotheses and bids" was elaborated in 2018 by participants of the Baikal Strategies Business Club. Inherently, this is the view of the business community of the Irkutsk Region on its future and development paths. A survey among authorities of the Russian Federation entities concerning powers in the system of strategic planning, held by the Analytical Center under the Government of the Russian Federation [2], has clearly shown a serious demand for modernization of the current system of regional strategic planning.

Thus, it is clear that the formation of a system of strategic planning documents at the regional level, as well as institutions involved in planning in Russian regions, is extremely important and yet not completed [3].

\section{Relevance. Literature review}

In the period of the $90 \mathrm{~s}$ of the $20^{\text {th }}$ and early $21^{\text {st }}$ century, the planning of socio-economic development of the country and regions was almost beyond the field of interests of the Russian

Corresponding author: Petr Iosifovich Burak, Institute of Regional Economic Research, Moscow, Russia. E-mail: pi.burak@mail.ru 
scientific society. The attention of Russian scientists was focused mainly on the study of issues of intracompany planning in the context of individual economic entities - enterprises, firms, and corporations. Planning at the national and regional levels was seen as a vestige of the command economy system being dismantled at that time. Suffice it to note that the federal law defining the basis for strategic planning of Russia's economy was adopted only in 2014 , i.e. more than 20 years after the beginning of market transformations.

In that period, a positive exception was the study of the theory and methods of long-range strategic planning and projection at the level of macroregions of the country, conducted by specialists of the Council for the Study of the Natural Productive Forces of the Russian Academy of Sciences in 2000-2005. Large-scale comprehensive research on the development of Russian macroregions in a market economy was carried out under the leadership of Academician A.G. Granberg, as well as the practical development of several strategic documents (concepts, programs) for the country's macroregions. The studies of this research team made it possible to update, develop, and expand the traditional concepts of territorial development that were formed during the period of a directive planned economy [4-6]. The preparation and adoption of the federal law "On Strategic Planning in the Russian Federation" in 2014 initiated the growth of scientific interest to the problem of economic planning, both at the national and regional levels. However, most of the published works and research (including broad-scale and high-quality studies) concern the development of long-term strategic indicative documents, such as concepts and strategies that liberal economic thought considers quite acceptable and useful in a market economy as a tool that ensures the relationship of national tasks with the practice of everyday economic activity. As an example, one should note an interesting study conducted by specialists of the Institute for Public Finance Reform under the leadership of V.V. Klimanov [7], and dealing with the problem of analyzing and evaluating the effectiveness of state programs for the microregions' development, elaborated in Russia in the first decade of the $21^{\text {st }}$ century. At the same time, issues of mediumterm planning at the regional level, improvement of its forms and methods, related to the new realities of the innovation and information economy as well as foreign economic challenges facing Russia in the $21^{\text {st }}$ century, are not sufficiently studied. Currently, the works of specialists, such as B.A. Reisberg [8, 9], A.R. Leibkind [10], L.S. Pekarsky [8] and O.M. Yun [11], relating to the period of the $80 \mathrm{~s}$ of the $20^{\text {th }}$ century, still remain the methodological and theoretical basis for medium-term planning in Russia including program-oriented projecting.

In these conditions, where the imperatives of the contemporary Russian regional economy, such as the need to ensure an innovative leap, develop import substitution, and intensify interregional ties, require increasing the level of conformity to plan, covering new economic objects (macroregions, commodity centers, priority development areas, science towns, and technopolises) with comprehensive regional planning, applying new planning methods and tools, conducting deep and comprehensive research to improve the planning of socio-economic development at the regional level seems to be very important.

\section{Methodology}

The research methodology of the problem posed includes a comprehensive, synthetic analysis of the following issues:

-profile scientific publications of leading Russian scientists regionalists;

-assessment of the regulatory framework for planning socioeconomic development, created in the regions of Russia;

- generalization of the experience of practical planning activities carried out in the regions - the subjects of the Russian Federation- at the present time.

This methodological approach made it possible to ensure the combination of existing theoretical developments on the topic with the results of practical planning activities in the regions of the country. For this, the authors carried out a content analysis of the regional regulatory framework on planning for the period 2015-2020 (for 85 constituent entities of the Russian Federation), studied the practice of forming strategic planning documents (concepts, strategies, programs, plans) in the city of Moscow, the Moscow region, Irkutsk region, Republic of Khakassia, Kaluga region. In addition, this article summarizes the personal experience of the authors who were directly involved in the development of regional strategic planning documents - the Investment Strategy of the Irkutsk Region for the period up to 2030 and the Complex of strategic investment initiatives of the Irkutsk Region for the period up to 2030.

\section{Results}

Analyzing the process of implementing the law on strategic planning, Russian researchers pay attention to the limitations in the content of the documents established by the law, their insufficient relationship and hierarchy, and the appearance of new strategic documents that are not provided for by the law [12-14]. In particular, there is an essential gap between the strategies of socio-economic development of regions and regional target programs intended for implementing strategies. The development of strategic documents for several important structural elements of the territorial organization of the country's economy, i.e. urban agglomerations, regions of the Russian Federation highly integrated economically (Moscow, the Moscow Region, SaintPetersburg, the Leningrad Region, Sevastopol, and the Republic of Crimea), is not provided. Also, the country's 14 macroregions are practically not covered by strategic planning.

A survey conducted in 2019 by the Analytical Center under the Government of the Russian Federation among the administrations of the Russian Federation entities has illustrated in detail the need to improve the system of strategic planning in the regions. According to the survey outcomes, the main regulatory, methodological and organizational problems of strategic planning processes were identified by experts as the lack of unity and interconnectedness of strategic planning documents, the inconsistency of their goals, tasks, deadlines and target indicators, insufficient powers of regional state authorities (noted by $10 \%$ of the Russian Federation entities) and municipalities, suboptimal, and sometimes excessive composition of strategic planning documents, low financial and human resource capacities, as well as insufficient statistics at the local level.

More than a third of the surveyed entities of the Russian Federation do not consider the composition and hierarchy of strategic planning documents developed at the regional level to be optimal. It is proposed to supplement them by industry documents of strategic planning of the region, documents of strategic planning of urban agglomeration, regional projects of the Russian Federation entity, as well as the spatial development 
strategy of the region, and the forecast of the labor resources balance. At that, according to the respondents, the mid-term projection of socio-economic development and the long-term budget projection should be excluded from the list of strategic documents. Also, respondents call the action plan for implementing the socio-economic development strategy of the Russian Federation a superfluous document [2].

Currently, the regions of the Russian Federation are intensively searching for new forms of planning for socioeconomic development, improving and advancing the system of regional planning documents. Several interesting innovations in the field of planning were implemented in the Irkutsk Region. In 2017-2019, the Irkutsk Region implemented a model of regional development that involved strengthening the planning process and required further improvement of all elements of the planning system. This refers to increasing the horizon of planning procedures, expanding the range of entities covered by planning, increasing the scientific level and validity of planning decisions, and creating new planning documents, and planning authorities.

In the Irkutsk Region, where a standard base of strategic planning documents has already been created, including a regional Strategy for socio-economic development until 2030, an Investment strategy until 2025, state programs, an anti-crisis plan, and investment messages from the governor, methodological and organizational work was carried out in 2018 aimed at creating a new document for strategic long-term planning at the regional level, namely, a Set of Strategic Investment Initiatives.

This document does not duplicate the regional strategic planning documents existing in the Irkutsk Region but complements them by revealing and specifying the directions for implementing the socio-economic development strategy of the region. This is achieved by identifying and justifying specific major projects in the field of management, industrial production and investment, ecology and environmental protection, social policy, and interregional cooperation.

In contrast to the Concept and Strategy of socio-economic development of the region, the set of strategic investment initiatives includes specific large-scale investment, management, and social projects with a deep degree of justification and feasibility study. The goals and objectives of each specific project are defined, as well as their contribution to the region's economy, budget revenues, and population's standard of living. At the same time, the approximate volume of necessary investments is estimated, and the circle of potential investors is outlined. The time horizon of the set of initiatives is 12 years.

The content of the work carried out within the framework of this new strategic document can be described as a combination of scientific research, long-term projection, business analytics, feasibility studies, information support, and expert support of managerial activities of regional authorities.

The set of strategic investment initiatives is aimed at extending cooperation and establishing strong ties between the Irkutsk Region and neighboring regions of the Baikal macroregion, as well as with the countries of the Eurasian Economic Union. Its ultimate goal is to ensure sustainable growth of the region's economy, the region's access to new markets, improving the population's standard of living, and boosting the Irkutsk Region in a leading position in the Siberian Federal District.

Considering the relationship of the new document with other long-term planning documents implemented in the Irkutsk
Region, its place in the top-down structure of concept - strategy - state regional program, it can be stated that it occupies an intermediate place between the strategy and programs. The Set of Strategic Initiatives concretizes the socio-economic development strategy of the region and ensures its practical expression. In turn, regional programs and plans should be considered as a tool for implementing individual strategic investment initiatives.

In the course of the formation of a Set of Strategic Initiatives in the Irkutsk Region, in 2018, selecting and justifying strategic investment projects (initiatives) up to 2030 were implemented in 2018. An expert group, specially created under the leadership of academician S. Glazyev, has selected 20 major investment projects for various sectors of the region's economy based on analytical research in cooperation with interested economic entities (major Russian corporations, enterprises, banks, and investment funds) and the economic bloc of the government of the Irkutsk Region. Of these, twelve initiatives relate to production (industry, transport, agriculture, energy), two initiatives concern the information economy, four initiatives refer to the services and housing and community amenities, and two initiatives refer to regional finance and budget.

How to assess the feasibility of developing such a document within the general logic of strategic planning, regulated by the federal law "On Strategic Planning in the Russian Federation"? It seems that the appearance in the hierarchy of strategic planning documents of an item that occupies an intermediate position between strategies and programs is largely justified and methodically useful. The gap in terms of the content between the highly aggregated content of socio-economic development strategies of the country and regions, and the specific content of state target programs, as noted above, is obvious. At the same time, if a set of investment initiatives is recognized as a fullfledged element of the system of strategic planning documents at the regional level, it would be necessary to thoroughly study the methodology for its development, the frequency of release and the planning horizon, as well as determine and form the composition of indicators.

Another innovation in the regional planning system in the Irkutsk Region is the development of a five-year State Plan for Socio-Economic Development for 2019-2023. The regional leadership considers it a central element of the goal-setting and strategic planning system of the Irkutsk Region. The plan aims at effective coordination of the work of state authorities, local governments, the business community, as well as rational and maximum efficient use of all the resources of the Irkutsk Region to ensure sustainable economic growth and welfare. The plan was developed using program-target planning and project design methods. All branch and functional divisions of the government of the Irkutsk Region took part in the preparation of the document, while the work was coordinated by a specially created body, namely, the Committee for Planning the Socio-Economic Development of the Irkutsk Region. The preparation of a fiveyear plan for the socio-economic development of the Irkutsk Region was carried out in the second half of 2018. The plan was approved by the order of the Governor of the Irkutsk Region and came into force on January 01, 2019 [15, 16].

Thus, the Irkutsk region is developing a new system of regional planning documents for socio-economic development, which is atypical in its structure for the regions of the Russian Federation, as part of a long-term strategy, a set of strategic investment initiatives, a five-year development plan of the region, 
and state programs $[17,18]$.

As already noted by the authors [19], at present, strategic planning does not cover all the territorial elements of the country's economy. This is about urban agglomerations and economically highly integrated regions of the Russian Federation. The authors believe that strategies and programs for the development of the urban agglomeration should become a new element of the hierarchical planning and projecting system within the Russian regions. In the current context, urban agglomerations play a leading role in the spatial organization of the economy and society, serve as resource concentration as well as accelerated development points, and provide economic growth, primarily due to new advanced knowledge-intensive industries and technologies. The Irkutsk Region, for example, incorporates a large urban agglomeration, namely, Irkutsk, which plays a leading role in the region's economy. According to 2018, the city of Irkutsk concentrated $32 \%$ of the total number of employees, $60 \%$ of assets, $56 \%$ of retail turnover, and $30 \%$ of the total area of new residential buildings being commissioned in the Irkutsk region [20].

The dominant role of urban agglomerations in the economy and innovative development of the country in general, and its regions, in particular, is a compelling reason for organizing targeted strategic planning for the development of agglomerations, as well as their current management. Nevertheless, there is practically no systematic and coordinated practical work on projecting and strategic planning of agglomerations' development in the country. This is because of the lack of an appropriate regulatory and methodological framework and plenipotentiary governance authorities.

Analysis of long-term planning documents developed to date for agglomerations has shown that these documents, in their overwhelming majority, relate to issues of territorial planning, urban planning, development of engineering infrastructure, and the formation of unified transport systems. These documents do not consider the economy of agglomerations, i.e. business relations of enterprises, cooperation, logistics, use of labor resources, and investment activities. All these features are typical, for example, for the Irkutsk Agglomeration Development Concept, elaborated in 2007 by the Regional Development Fund of the Irkutsk Region. Meanwhile, it is these issues that should be the goal-setting and regulation objects in agglomerations' development strategies. According to the authors, the inclusion of urban agglomerations' development strategies and programs in the regional planning system will raise the economic relations of enterprises and firms located in agglomerated territories to a fundamentally new level, increase the pace and scale of innovation, ensure the rational use of labor, minimize the negative impact of urban agglomerations on the environment, i.e. turn them into economic growth centers across the country and regions.

To prepare and subsequently implement new types of regional planning documents and, in general, strengthen the planned impact on the regional economy, it is necessary to form appropriate planning bodies. For example, to ensure the implementation of the above-mentioned five-year state plans in the Irkutsk Region, special management and planning body named the State Committee for Planning the Socio-Economic Development of the Irkutsk Region was established in July 2018. It is noteworthy that according to the regulatory documents, the State Committee is established in the format of a collegial body under the governor of the region. The State Committee, along with the heads of executive authorities of the Irkutsk Region, includes executives of joint-stock companies, the staff of higher educational institutions, nonprofit organizations, scientists, and experts, including those from other regions of the country. Decisions of the State Committee are made by a majority vote of its members and are mandatory for the executive authorities of the region.

At the moment, it is difficult to talk about the effectiveness of this new planning institution. However, the lack of permanent staff of the State Committee provokes doubt concerning the ability to provide a deep, comprehensive, and thorough study of economic and social problems in the region, to prepare planning documents, fundamentally different in their quality than the existing ones. Eventually, currently, the work on shaping a fiveyear plan is carried out by specialists of industry and functional divisions of the Irkutsk Region's government.

\section{Discussion}

The assessment of innovations and creative searches in the course of strategic planning of the economy in the Russian regions, and the content of scientific discussions among scientists-regionalists allow putting forward the following conceptual proposals aimed at improving the system and tools of strategic planning at the regional level. The strategic planning system should include new economic objects that have been developed within the regions as Russian Federation entities but have not yet been covered by planning. This concerns urban agglomerations, large territorial and industrial complexes, singleindustry towns, priority development areas, etc. It is advisable to strengthen the coordination of strategic planning processes and mechanisms of regions and municipalities. It is necessary to continue working on improving the system of strategic planning documents in the regions, enriching it with new types of planning documents (for example, a set of strategic investment initiatives).

It is expedient to adjust and improve indicators for regional planning documents to allow better reflecting the current goals and objectives of regional development, i.e. creating innovative industries, developing interregional economic relations, implementing import substitution, rising standards of living and incomes, and ensuring effective environmental management. Developing strategic planning documents in the regions in the current context should be carried out using the opportunities provided by information technology. Electronic exchange of information, processing of large amounts of data, the interaction of specialists in electronic networks, management, and control in real-time mode allow radically expanding the horizons and scope of planned decisions while maintaining reasonable sufficiency of the number of planned parameters, the validity of decisions, and the efficiency of the planning process. It is necessary to form competent and responsible strategic planning bodies in the regions of the Russian Federation that can carry out this work at a new technical and methodological level. In particular, it is important to create multilateral coordination bodies for strategic planning for highly economically integrated Russian Federation entities (Moscow - Moscow Region, Saint Petersburg Leningrad Region, Sevastopol - Republic of Crimea). It is advisable to introduce uniformity in the process of developing and approving strategic planning documents in the regions, set deadlines, and responsibility for their compliance. For example, in the Irkutsk Region, the regional legislature could not approve 
a strategy for the socio-economic development of the region until 2030 for two years. This situation devalues the developed documents, reduces their relevance, and discredits the very planning process.

\section{Conclusion}

At present, there is an obvious need in Russia to extend the scope of coordinating economic decisions, and management activities, as well as to improve long-term goal-setting within the national economy and economic complexes of the Russian Federation entities. Improving the level of planned economic development, implementing strategic plans and programs are a method that has been tested by many countries when solving social problems, overcoming economic backwardness, and achieving an innovative breakthrough. All this is also relevant to Russia. In contemporary Russia, there is a unique opportunity to quickly and radically increase the level of planning of the regional economy, to reorient it towards a social result without shock therapy, social disasters, and political violence. This can be achieved based on the following prerequisites:

- Availability of recent historical experience (positive in many aspects) in strategic, medium-term and operational planning of Russia's economy and its regions;

- The opportunity to study and use the experience of friendly foreign countries that are currently using planning tools in their economic practice very successfully;

- Availability of a serious scientific background created recently by Russian scientists in the organization of the country's economic planning in the prevalence of market relations;

- The presence of political will and public support for the radical strengthening of the planned foundations of the national economy in the face of opposition political parties and public organizations, including those representing the business community;

- Finally, the availability of the Russian Federation entities that are ready to act as pioneer territories, polygons for expanding and deepening the scope of application of planned mechanisms for managing the economy, working out, and implementing new planning methods and tools in economic practice.

The current system of strategic planning in the regions of the Russian Federation is imperfect, and, according to the authors, the above proposals will make it a more effective tool for solving urgent problems of economic development.

\section{Aknowledgment}

The article was prepared with the financial support of the Russian Foundation for Basic Research (RFBR). Project No. 20010-00265.

\section{Ethical issue}

Authors are aware of, and comply with, best practice in publication ethics specifically with regard to authorship (avoidance of guest authorship), dual submission, manipulation of figures, competing interests and compliance with policies on research ethics. Authors adhere to publication requirements that submitted work is original and has not been published elsewhere in any language.

\section{Competing interests}

The authors declare that there is no conflict of interest that would prejudice the impartiality of this scientific work.

\section{Authors' contribution}

All authors of this study have a complete contribution for data collection, data analyses and manuscript writing.

\section{References}

1. Order of the Government of the Russian Federation of 13.02.2019 No. 207-r. "Ob utverzhdenii strategii prostranstvennogo razvitiya Rossijskoj Federacii na period do 2025 goda" [On approval the Strategy of the spatial development of the Russian Federation up to 2025]. Sobranie Zakonodatel'stva Rossiiskoi Federatsii [SZ RF] [Collection of Legislation of the RF] 18.02.2019, No. 7 (Part II), Item 702 .

2. Analytical Center under the Government of the Russian Federation. Inventarizaciya polnomochij sub"ektov Rossijskoj Federacii $i$ organov mestnogo samoupravleniya $v$ sfere strategicheskogo planirovaniya [Inventory of powers of the Russian Federation entities and local self-government bodies in the strategic planning]; 2019. Available from: ac.gov.ru

3. Strategicheskoe planirovanie: problemy i perspektivy realizacii $v$ sisteme gosudarstvennogo upravleniya ekonomikoj [Strategic planning: Problems and prospects of implementation in the system of state management of the economy]. Moscow: Ekonomika; 2012. 300 p.

4. Granberg AG, Shtul'berg BM, Kichedzhi VN. Strategii makroregionov Rossii: metodologicheskie podhody, prioritety i puti realizacii [Strategies of Russian macroregions: Methodological approaches, priorities, and ways of implementation]. Moscow: Nauka; 2004. 20 p.

5. Shtulberg BM. O koncepcii territorial'nogo razvitiya Rossii [On the concept of territorial development of Russia]. Fuel and Energy Complex. 2005; 3-4:24-31.

6. Shtulberg BM. Dolgosrochnoe prognozirovanie territorial'noekonomicheskogo razvitiya Rossii (metodologicheskie osnovy i prognoz na period do 2015 goda) [Long-term projecting of territorial and economic development of Russia (methodological bases and projection up to 2015)]. Moscow: Council for the study of productive forces; 2002.

7. Klimanov VV. Gosudarstvennye programmy razvitiya makroregionov Rossii: podhody $\mathrm{k}$ analizu [State development programs for macroregions of Russia: Approaches to analysis]. Moscow: URSS, Lenand; 2016. 194 p.

8. Reisberg BA, Pekarsky LS. Kachestvo planovo-upravlencheskoj raboty [Quality of planning and management work]: Issues of Methodology and Practice. Moscow: Economics; 1987.

9. Reisberg BA, Lobko AG. Programmno-celevoe planirovanie i upravlenie [Program-target planning and management]. Moscow: INFRA-M; 2002. 428 p.

10. Leibkind AR, Rudneva EV, Rudnik BL. Problemy metodologii i organizacii razrabotki kompleksnyh programm [Methodology and organization problems of complex programs development]. Moscow: Nauka; 1983.110 p.

11. Yun OM. Intensifikaciya ekonomiki: teoriya i praktika planirovaniya [Intensification of the economy: Theory and practice of planning] Moscow: Economics; 1986. 374 p

12. Burak PI. Formirovanie sistemy strategicheskogo planirovaniya na regional'nom urovne: Nauchno-metodicheskoe obespechenie [Formation of the strategic planning system at the regional level: Scientific and methodological support]. Problems of Management Theory and Practice. 2004; 11:58-64. 
13. Ivanov OB, Bukhvald EM. Ukazy prezidenta RF kak instrumenty strategicheskogo celepolaganiya $\mathrm{v}$ rossijskoj ekonomike [Decrees of the President of the Russian Federation as tools of strategic goal setting in the Russian economy]. ETAP: Economic Theory, Analysis, Practice. 2019; 3:7-24.

14. Miroshnikov SN. Problemy i napravleniya strategicheskogo planirovaniya $\mathrm{v}$ regional'nom razvitii [Strategic planning problems and directions in regional development]. ETAP: Economic Theory, Analysis, Practice. 2019; 4:61-77.

15. Decree of the Governor of the Irkutsk Region of 09.07.2018 No. 135 ug. "On the State Committee for the planning of the socio-economic development of the Irkutsk Region". Available from: http://publication.pravo.gov.ru/Document/View/3800201807100002

16. Order of the Governor of the Irkutsk Region of 09.07.2018 No. 87-R "On the composition of the State Committee for the planning of socio-economic development of the Irkutsk region". Obshchestvenno-politicheskaya gazeta "Oblastnaya" [Social and political newspaper "Regional"] 16.07.2018, No. 76.

17. Levchenko SG, Balashov YeB, Burak PI. Gosudarstvo razvitiya. Effektivnaya ekonomicheskaya model' razvitiya strany i regionov. Opyt realizacii v Irkutskoj oblasti: monografiya [The country of development. An effective economic model for the development of the country and regions. Experience of implementation in the Irkutsk Region: a Monograph]. Moscow: Ekonomika; 2018. 267 p.

18. Levchenko SG, Balashov YeB, Barsukov IYe. Gosudarstvo razvitiya. Model' planovoj transformacii ekonomiki strany i regionov: metody i praktika realizacii v Irkutskoj oblasti [The country of development. Model of the planned transformation of the country's and regions' economy: methods and practice of implementation in the Irkutsk Region]. Moscow: Ekonomika; 2019. 271 p.

19. Burak PI, Rostanets VG. Strategicheskoe planirovanie ekonomicheskogo razvitiya gorodskih aglomeracij v Rossijskoj Federacii: metodicheskie i organizacionnye problemy [Strategic planning of economic development of urban agglomerations in the Russian Federation: Methodological and organizational problems]. Bulletin of the Russian Academy of Natural Sciences (RANS). 2017; 17(3):108-112.

20. Territorial authority of the Federal State Statistics Service for the Irkutsk Region. Available: https://irkutskstat.gks.ru/ 